\title{
Analysis of the Film 'No Gold for Kalsaka' in terms of the Right to Economic Self-Determination
}

\section{'No Gold for Kalsaka' Filminin \\ Ekonomik Kendi Kaderini Tayin Hakkı Bakımından İncelenmesi}

\author{
Selim Misafir ${ }^{1}$
}

\begin{abstract}
Colonialism activities in Africa have turned into an economic exploitation system by multinational companies rather than the use of occupy and power as in past. A recent case in Kalsaka, which has gold mine deposits in Burkina Faso, is a concrete instance of this. The people of Kalsaka suffer greatly because of unfair interventions in their natural resources. The film 'No Gold for Kalsaka' is a motion picture that carries these grievances in Kalsaka to the screen. When entered the door that the film opens, the legal perspective on the subject takes shape. One of the legal norms that can be applied is the right to economic self-determination which ensures the permanent sovereignty over their natural resources. In that sense, steps can be taken to compensate the damages of Kalsaka people based on the authority given by this right which includes the rights to own, use and benefit from natural resources. Accordingly in this study, firstly, the legal framework of the right to economic self-determination is drawn. Secondly, the said documentary film is analysed in the context of the relationship between law and cinema, and finally, the film's narrative about the events in Kalsaka is associated with the mentioned right.
\end{abstract}

Keywords: colonialism, Africa, the right to economic self-determination, the film No Gold for Kalsaka, cinema, human rights.

\section{Öz}

Afrika topraklarında geçmişteki işgalci ve güç kullanımına dayanan sömürgecilik faaliyetleri, günümüzde yerini çokuluslu sermaye şirketleri eliyle ekonomik sömürü düzenine bırakmıştır. Burkina Faso'nun altın madeni yataklarına sahip Kalsaka kasabasında yakın zamanda yaşananlar, bunun somut bir örneğidir. Kalsaka halkı, doğal kaynakları üzerinde gerçekleştirilen haksız müdahaleler nedeniyle büyük bir mağduriyet ile karşı karşıya kalmıştır. 'No Gold for Kalsaka' filmi, kamerasını bu hukuksuz manzaralara çevirerek Kalsaka'da yaşananları sinema perdesine taşıyor. Filmin oluşturmaya çalıştı̆̆ kamuoyu dikkate alınarak araladığı bu kapıdan girildiğinde, konuya ilişkin olarak hak savunuculuğu anlamında hukuki bakış açısı şekillenmektedir. Bu anlamda, Kalsaka'da sergilenen hukuka aykırı muamelelere karşı başvurulabilecek hukuki kurumların başında ekonomik kendi kaderini tayin hakkı geliyor. Kalsaka halkının doğal kaynakları üzerindeki sürekli egemenliklerini güvence altına alan bu hak, maruz kaldıkları eylemler karşısında gündeme gelebilir ve hukuki sorumluluklar doğurabilir. Bu çerçevede, Kalsaka halkının doğal kaynaklara dayanan zenginliklere sahip olma, kullanma ve yararlanma haklarını intiva eden bu hakkın verdiği yetkiye dayanarak uğradıkları zararların tazminine yönelik adımlar atılabilir. Bu tespitlerle birlikte çalışmada, ilk olarak kendi kaderini tayin kavramının ve ekonomik kendi kaderini tayin hakkının hukuki çerçevesi çiziliyor. Daha sonra, adı geçen belgesel filmin hukuk ve sinema etkileşimi bağlamında tahlili yapılıyor ve son olarak, filmin Kalsaka'da yaşananlara ilişkin anlatısı ekonomik kendi kaderini tayin hakkı ile ilişkilendiriliyor.

Anahtar Kelimeler: sömürgecilik, Afrika, ekonomik kendi kaderini tayin hakkı, No Gold for Kalsaka filmi, sinema, insan hakları.

Araștırma Makalesi (Research Article)

Gönderim Tarihi (Received):28.02.2021

Kabul Tarihi (Accepted):10.05.2021
Atıf (cite as): Misafir, S. (2021). Analysis of the Film 'No Gold for Kalsaka' in terms of the Right to Economic Self-Determination. Akdeniz Üniversitesi İletișim Fakültesi Dergisi, (35), s. 284-298, DOI: 10.31123/akil.887987 


\section{Introduction}

Kalsaka is a small town located approximately 125 kilometres northwest of Ouagadougou, the capital city of African country of Burkina Faso. The people of Kalsaka earn their living by processing the gold extracted from local soils which they have as a natural resource since old times. However, this historical subsistence business based on traditions ended with the activities of a multinational mining company that exploited raw materials and abandoned without providing anything to the local population due to the expropriation of the lands of local property owners by the government.

In the early 2000s, the government of Burkina Faso allowed a few multinational companies to mine in country territory, which was the beginning of the rush to gold mines in this African land. For this purpose, the first industrial gold mine was built in Kalsaka in June 2006 by the company Kalsaka Mining S.A. ${ }^{2}$ to extract 18 tons of gold in a 10-year period according to the agreement. However, this company left Kalsaka, leaving an economic, social and environmental disaster after six years of operations.

The people of Kalsaka maintain their livelihood by processing gold from their natural resources since the ancient eras. This ends with the arrival of a multinational mining company that carried out destructive activities on local land in 2008. The company ended its mining activities in Kalsaka after extracting 18 tons of gold. Nowadays, local people are faced with the fact that their promises are not fulfilled, and their natural resources are exploited. They have started to learn their rights and are fighting for justice.

The film 'No Gold for Kalsaka', made as a documentary movie, is a product of independent cinema that focuses on this struggle for justice and human rights. With the words of the storyteller in the film, the people of Kalsaka are ready to fight for the reparation of their rights as brave men and brave women. The following legal interpretations have been considered arguable in this article, based on the associations of the film which happen to the local people in a fictional and striking scenario technic, reflecting the bad practices.

The subject of self-determination can come first among the human rights theories to be used to justify the lawlessness experienced by the inhabitants of Kalsaka. The people of Kalsaka can engage in a struggle for rights against companies operating on their lands and persons and organizations responsible for violations of their right to economic self-determination.

In this regard, firstly, this study will focus on self-determination from a legal perspective and the international human rights law framework of the right to self-determination. Secondly, the film 'No Gold for Kalsaka' will be analysed in the context of the correlation between law and cinema and finally the film will be resolved in relation with the right to economic self-determination.

2 Cluff Gold PLC group, a British company based in London, had a 90 percent on the shares of Kalsaka Mining S.A. The remaining 10 percent share was allocated to the State of Burkina Faso (Extractive Industries Transparency Initiative, 2011).

Regarding the gold mining activities of Cluff Gold in Kalsaka, Algy Cluff, the chairman and the CEO of the corporation said in that time: "It is our intention to increase the capacity of the plant at Kalsaka and to increase our resource base such that the Kalsaka gold mine becomes the hub for the development of satellite deposits in this area. With the increased throughput, we believe we will achieve better than our forecast production for the year and lower cash cost per ounce." (Proactive Investors, 2009, para. 4).

In relation to the Cluff Gold's mining activities focused on West Africa, see also (Jamasmie, 2012).

The company Cluff Gold changed its name to Amara Mining PLC in 2012 (Van Wyngaardt, 2012). 


\section{The Concept of Self-Determination}

Self-determination can be defined as a peoples' free determination of its own legal and political status as a separate entity, preferably like an independent state. It is also a peoples' free will on its own economic, social and cultural system, without being subjected to external pressure. Cassese emphasizes that it would be wrong to consider self-determination as one norm, and states that it exists in two aspects as a general principle and a certain rule. At this point, we can talk about two groups of approaches, minimalist and maximalist, that give meaning to the subject. According to the minimalist approach, it would not be appropriate to consider self-determination as a right in international human rights law or to approach separation by equating it. Maximalists, on the other hand, examine self-determination in a broad framework and deal with it in economic and cultural terms.

After the World War II and with the establishment of the United Nations (UN), self-determination gains an anti-colonial meaning, and after the period of empires, this time it undertakes the role of closing the colonial period. In this period, human rights and self-determination have become the basis of international law and international organizations (Bauböck, 2004, p. 8). The UN Charter, for example, refers twice to self-determination, which will be discussed in more detail later. Article 1 of the UN Charter and other international agreements now clearly contain two things: i) internal self-determination (the right of peoples to determine their social, economic and cultural policies) and ii) external self-determination (the right of peoples to freely determine their international status). Internal self-determination, previously interpreted as individual rights, has now been expanded to include civil and political rights (Cassese, 1995, p. 122).

It should not be forgotten that self-determination, which is one of the most essential aspects of individual autonomy, reflecting the natural jurist understanding and the product of the enlightenment philosophy, is inherent to human rights and human dignity. And it must be remembered that human rights, as a universal value adopted by national and international society, are inherent to human dignity as a systematically (Nowak, 2018, p. 9) phenomenon. On the other hand, human dignity is the most fundamental argument in terms of philosophical and politics for human rights to have a natural and universal character (Nowak, 2018, p. 27).

It will be beneficial to open a parenthesis to the concept of self-determination in the framework of colonialism and touch upon its adventure in Africa, where it could have its most concrete aspects with this context. At the same time, it should be kept in mind that the geography the film takes place is in the African continent, and the violations of the right to self-determination deduced from the film take place in the African land.

\subsection{The African History of Self-Determination}

The attempts to end colonialism in Africa in the post-world wars period were effective in the importance of self-determination under the UN system. Thus, the process of self-determination that occurred after the World War I was repeated after the World War II. The decolonization in the African continent acted as a chain reaction, and countries started to gain independence one by one, based on the right to self-determination. Especially the peoples dominated by a geographically distant colonial power were immediately given this right. 
Independence movements in the axis of self-determination in Africa have displayed a single feature. Although African peoples acted under the name of self-determination, they demanded political independence by considering the boundaries that were not based on ethnic distribution, dominated, or ruled by former colonial powers and were essentially randomly drawn (Connor, 1994, pp. 5-6). In addition, in post-colonial states, it appeared to be a proposal based on self-determination, human rights, political and legal rights, and morals. In other words, self-determination here rather meant the development of human rights, and was kept away from its original purpose. This situation upset the thesis of using self-determination for purposes such as determining the land border, governing peoples' own state, and obtaining special rights especially regarding natural resources (Zhu \& Biachford, 2006 pp. 37-38).

Self-determination for the third world countries meant the challenges to colonialism and racism, and it included struggles against an oppressive state domination that occupied a country without consent and against all the emergence of neo-colonialism (Cassese, 1995, pp. 45-46). So much so that self-determination had priority over principles such as the prohibition of the use of force and non-interference in internal affairs. Truly, it was seen as a majority rule (Oran, 1997, p. 111).

As a matter of fact, the UN accelerated its efforts in the 1950s and 1960s, when African nationalism was on the rise, and focused its efforts on the realization of the right to self-determination in the colonies and guardianship regions. In the 1950s, the UN dealt with the issue of the independence of Morocco, Tunisia and Algeria, in response to the demands of the southern countries, it approved the right of peoples to freely determine their own futures and self-control over their own resources, and the UN adopted the Tunisia and Bangkok declarations on this matter (Özdek, 2000, p. 375). But self-determination, which was effective in liberating from colonialism, has also faced certain obstacles, as later demonstrated by the crises on the future of the Western Sahara and Palestinian peoples (Chemillier-Gendreau, 1998, p. 131). In the third world, both the UN, the Arab League and the African Union have contributed greatly to the fact that self-determination is a rule of law that gives rise to rights and obligations (Pazarcı, 2013, p. 221).

Precisely at this point, before moving on to the legal scope of the right to self-determination, since Kalsaka, where the experience of violation of the right to self-determination is the subject of this study, is located in Africa, the existing and main regional legal regulations on the right to selfdetermination in Africa can be briefly addressed. In the Preface to the Addis Ababa Charter, which established the Organisation of African Unity, and in the Article 20 of the African Charter on Human and Peoples' Rights, the right to self-determination has been accepted (Pazarcı, 2013, p. 221). The relevant Article 20 is as follows:

"1. All peoples shall have the right to existence. They shall have the unquestionable and inalienable right to self-determination. They shall freely determine their political status and shall pursue their economic and social development according to the policy they have freely chosen.

2. Colonized or oppressed peoples shall have the right to free themselves from the bonds of domination by resorting to any means recognized by the international community.

3. All peoples shall have the right to the assistance of the State Parties to the present Charter in their liberation struggle against foreign domination, be it political, economic or cultural." (African Union, n.d.). 


\subsection{The Legal Scope of the Right to Self-Determination}

The right to self-determination is not a human right vested in individuals or states. The peoples are the owner of this right. However, one of the most prominent issues about self-determination is the criteria by which the peoples, the subject of the right, will be determined. The definition of the peoples differs according to place, group, and time. Crawford, as the subject of the right to self-determination outside the colonial context, sees the entire population of the state (Crawford, 2001, pp. 64-65). Bauböck (2004, pp. 14-15), on the other hand, emphasizes that the right to selfdetermination means that the colonized peoples express their will freely, and clarifies the holder of this right as peoples who live on a certain land.

Today, the issue of whether self-determination is jus cogens as an irrefutable right that has been given to the peoples by the legal order has gained importance. On the one hand, the importance of the Vienna Convention on the Law of Treaties -Article 53 of the Convention regulates jus cogens (United Nations, n.d.)- on the legal ground, and on the other hand, the inclusion of the self-determination in the most important contemporary international human rights law documents, have recently led to an increase in the view that the normative structure of the self-determination is in the nature of jus cogens. (Gardam, 1993, p. 49).

The main provisions of international human rights law on the subject, which constitute the basic framework of the legal scope of the right to self-determination, provide a legal basis especially for the economic dimension discussed in this study. The articles in which self-determination is explicitly and directly included in the UN Charter are the 2nd paragraph of the 1st article where the UN purposes and principles are regulated, and the article 55 of the 9th section where the international economic and social cooperation is regulated. Paragraph 2 of Article 1, which specifies the purposes and principles of the UN, is as follows:

"To develop friendly relations among nations based on respect for the principle of equal rights and self-determination of peoples, and to take other appropriate measures to strengthen universal peace." (United Nations, n.d.).

The 55th article of Chapter 9, which regulates economic and social cooperation, and constitutes the basic mechanism (Bring, 2003, p. 24) of the Charter by mentioning about ensuring peace and friendship relations, is as follows:

"With a view to the creation of conditions of stability and well-being which are necessary for peaceful and friendly relations among nations based on respect for the principle of equal rights and self-determination of peoples ..." (United Nations, n.d.).

The Declaration on the Granting of Independence to Colonial Countries and Peoples, resolution 1514 (XV) of the General Assembly of the United Nations as another significant international human rights law instrument on the right to self-determination, consists of an introduction and 7 articles. The clear provisions of the Declaration that should be underlined on the subject are as follows:

"... Solemnly proclaims the necessity of bringing to a speedy and unconditional end colonialism in all its forms and manifestations; And to this end declares that:

1. The subjection of peoples to alien subjugation, domination and exploitation constitutes a denial of fundamental human rights, is contrary to the Charter of the United Nations and is an impediment to the promotion of world peace and co-operation.

2. All peoples have the right to self-determination; by virtue of that right they freely determine their political status and freely pursue their economic, social and cultural development." (United Nations, n.d.). 
While the Declaration states that all peoples have the right to self-determination, it emphasizes the need to end colonialism quickly and without any conditions. It proclaimed that 'all peoples have the right to self-determination' in a way that creates rights for all the lands and peoples of the World (Tomuschat, 1993, p. 1). According to Potier (2001, pp. 25-26), although the right is expressed for all peoples in this Declaration, what is meant is the peoples under colonial rule. Even so, this right is in question for all peoples of the world, within the specified conditions, as the UN takes the whole world, not a specific region, in its subsequent applications and decisions. With the Declaration, the nature of self-determination has changed, it has ceased to be a legally recognized principle and has become an international right. The Declaration further developed Article 1/2 of the UN Charter, raised self-determination from a 'principle' position to an international 'right', and gave certainty (Bring, 2003, p. 25).

International Covenant on Civil and Political Rights (ICCPR) and International Covenant on Economic, Social and Cultural Rights (ICESCR) known as the Twin Covenants on Human Rights clearly affirmed the right to self-determination, and introduced new variants. Cassese (1995) points out that although the prevailing view related to the right meant liberation from colonial rule during this period, the concept gained a much broader meaning with these Covenants. He summarizes this in four items. Firstly, peoples living in States party to the Covenants have gained the right to freely elect their own rulers. Thus, the inner side of the right has been embodied. Secondly, it imposes the obligation on States parties to refrain from impeding the independence of other states, and the occupation of foreign lands violates the peoples' right to self-determination. Thirdly, the provisions of the UN Charter on colonial countries have been revived. Finally, with the emphasis on the right to control natural wealth, the economic aspect of the right, previously thought only to be political, has also emerged (pp. 65-66).

The right to self-determination is regulated in the joint Article 1 of both Covenants as follows:

"1. All peoples have the right of self-determination. By virtue of that right they freely determine their political status and freely pursue their economic, social and cultural development.

2. All peoples may, for their own ends, freely dispose of their natural wealth and resources without prejudice to any obligations arising out of international economic co-operation, based upon the principle of mutual benefit, and international law. In no case may a people be deprived of its own means of subsistence.

3. The States Parties to the present Covenant, including those having responsibility for the administration of Non-Self-Governing and Trust Territories, shall promote the realization of the right of self-determination, and shall respect that right, in conformity with the provisions of the Charter of the United Nations." (United Nations, n.d.).

The general phraseology preferred in the common 1st Article of the Twin Covenants expanded the right to self-determination not only to the peoples of the countries under the colonial rule, but to all peoples, thus establishing a continuous connection between civil and political rights (Gardam, 1993, p. 54). The right within the framework of the Covenants has become a continuing right, not ending with the achievement of independence. It is understood from the form of regulation in the article that the exercise of the right is not a one-time use, but a (dynamic) permanent right that must constantly renew and strengthen itself.

In Article 1/2, which is the common provision of the Covenants, the right's economic dimension, which is expressed as the free use of their natural wealth and resources and not depriving them of their own livelihoods, is regulated. Thus, the economic dimension of the right is included as well as its political dimension. The inclusion of the right in both Covenants can be interpreted as perceiving 
this right as both a civil and political right, as well as an economic, social and cultural right. In addition, the fact that this concept is included in a separate section of the contracts gives the right a privileged position in a sense (Crawford, 2001, p. 27).

The Declaration on the Right to Development, adopted by Resolution 41/128 General Assembly of the United Nations, emphasizes that the right to self-determination is one of the elements that ensure the development of peoples. It also accentuates that the development of peoples cannot be achieved if this right is not recognized. Article $1 / 2$ in which these points are stated is as follows.

"The human right to development also implies the full realization of the right of peoples to self-determination, which includes, subject to the relevant provisions of both International Covenants on Human Rights, the exercise of their inalienable right to full sovereignty over all their natural wealth and resources." (United Nations, n.d.).

\section{The Right to Economic Self-Determination}

Soon after the colonial peoples began to gain their political independence, it has understood that this turned out to be a little step on the road to real independence. The main problem arose with the demands of newly independent states to full sovereignty over their natural resources at the UN (Cassese, 1995, p. 99). The sovereignty of the colonial countries over their own economic resources became part of the law of self-determination over time, and this sovereignty became a right that can be claimed not only against the "ruling state", but against all states (Akçay, 1998, p. 31). The right to economic self-determination has become a human right that independent states could achieve only in the mid-20th century. At this stage, the legal nature and economic reasons of the issue were attempted to be determined (Tarhanlı, 1991, p. 142).

Sovereignty over natural resources is an extension of territorial sovereignty, and the constant sovereignty of states over natural resources has become an integral part of the right to selfdetermination. On this dimension, the right means that peoples can freely determine their economic future, freely exploit the natural wealth in their countries, and benefit from them as they wish, limiting or ending foreign economic interests when they see it necessary (Akçay, 1998, p. 37). For instance, if a state or international corporation has acquired an oil or gold privilege and operation over a country, and that oil or gold is the country's sole and primary source of livelihood, that country may amend, terminate, or nationalize the business and activities (Bilge, 1959, p. 141). This situation can be evaluated as an interference with the economic right to self-determination over natural resources, and may mean a violation of the economic right to self-determination. With the rise of capitalism with the global initiatives of international capital companies, and thus the transformation of the colonial understanding by changing face, the importance of the economic dimension is increasing day by day, especially in terms of the internal right to self-determination.

There are three substantial international human rights law documents of the General Assembly of United Nations that are directly effective in the formation and development of the right to economic self-determination in question. The first of these is the Right to Exploit Freely Natural Wealth and Resources Resolution dated December 21, 1952 and numbered 626 (VII) (United Nations, n.d.). The period in which the right is evaluated to include indefinite sovereignty over natural resources and wealth begins with this Resolution (Tarhanlı, 1991, p. 149).

Secondly, the right was legitimized in and its scope and rules were laid down with the Permanent 
Sovereignty over Natural Resources dated 14 December 1962 and numbered 1803 (XVII) (United Nations, n.d.). This scope consists of the discovery, development and disposal of resources. In this context, the economic right to self-determination includes certain rules: i) Sovereignty over resources should be exercised for the benefit of the peoples; ii) Foreign investments should not restrict the state's right to sovereignty over its natural resources; iii) Nationalizations should be made in the national or public interest; iv) In case of nationalization, appropriate damages and expenses should be paid; v) Nationalization should not be applied in a discriminatory manner; vi) In the event of a dispute, after the internal remedies of the relevant state have been exhausted, the state parties may submit the problem to arbitration or international judicial remedies (Pazarcı, 2013, pp. 26-27).

Finally, the Charter of Economic Rights and Duties of States (United Nations, n.d.), adopted with the Resolution No. 3281 (XXIX) dated December 12, 1974, is based on the idea of New International Economic Order (NIEO). Indeed, today's economic right to self-determination is also based on NIEO. In the Resolution, it is stated that states have exclusive and indefinite full sovereignty over their natural resources and wealth (Tarhanlı, 1991, p. 142).

Similarly, in the common Article 1/2 of the Twin Covenants, it is stated that peoples have the right to freely continue their economic development (Balcı \& Sönmez, 2001, p. 99). Again, in Articles 47 of ICCPR and 25 of ICESCR state as: "Nothing in the present Covenant shall be interpreted as impairing the inherent right of all peoples to enjoy and utilize fully and freely their natural wealth and resources." (Casssese, 1995, p. 100). Likewise, the Declaration on the Right to Development included this dimension of the right by referring to the Twin Covenants (Balcı \& Sönmez, 2001, pp. 210-211). Although the economic rights of the peoples are not directly associated with the right to self-determination in the aforementioned provisions, it has been accepted that economic selfdetermination is in question if it is exercised against the exclusive interests of a colonial or foreign power subjugation.

International arbitration decisions have also confirmed the right to economic self-determination. Two cases in 1977, the Topco-Calasiatic Case and the Liamco Case, can be cited as examples of these decisions. The Topco-Calasiatic Case was decided on January 19, 1977, and the Liamco Case on April 12, 1977. In the Topco-Calasiatic Case; the plaintiff is Texaco Overseas Petroleum/California Asiatic Oil Company, the defendant is the Libyan government, and the arbitrator is Dupuy. The case was filed after Libya nationalized its foreign oil partnerships in 1971 and 1974. The arbitrator did not see the company's claims as remarkable, and judged that Libya was right (Tarhanlı, 1991, p. 151).

In short, according to substantive law rules and established legal practices, peoples cannot be deprived of the right to benefit from their natural resources and wealth, which are necessary for their survival, and they have absolute sovereignty over their natural resources without any external pressure. The right to economic self-determination is the most essential law argument and legal infrastructure on these stated issues.

\section{The Correlation between Law and Cinema}

The concept of communication defines objects, concepts and events in the routine life of human beings. Electronic media, which has become the most effective form of communication today, enables the rules and practices to be questioned, and leads to individual and social changes on 
personal and communal life. (McLuhan, 2005, p. 8). Assuming social roles as a social entity, human beings maintain their lives with the roles assigned to them, and thus, by contributing to the existence of the society of which they are a member, they almost put a brick in the construction of social history. Cinema, which is the product of human being as a social entity, is also historical and social (Yaylagül, 2018, p. 129).

The effect of art to change and transform individual and collective thoughts is enormous (Kolker, 2018, p. 4). Cinema, which has a revolutionary perspective, is a political phenomenon (Monaco, 2014, p. 249). As with all works of art, every film shot in the cinema necessarily carries a social content. Some films have been inspired by a social event in recent or distant history, some of them question the state's government policies, while others are about the corruption in the administration of the country. In this sense, the genre of cinema, which aims to raise awareness among its viewers, is referred to as political cinema in the doctrine (Dorsay, 2003, p. 39). According to this, when broadly considering the concept of politics which surrounds every aspect of life, it can easily be said that the film is an example of the political cinema.

Cinema films raise unique awareness on human rights violations. They can draw the attention of the public to specific countries or regions where human rights are violated, and can be the voice of those whose rights are violated. Cinema, which contributes to gain a new awareness and cultural style of social reality (Ryan \& Kellner, 2016, p. 35), is an arena of cultural representation (Ryan \& Kellner, 2016, p. 36). Films encode the discourses of social life and convey them with cinematic reflections. (Ryan \& Kellner, 2016, p. 33). A movie is often inspired by an event in real life. Cinema, in which a new dimension is added to art (Bazin, 1993, p. 59), benefits from narratives that reflect the bittersweet events experienced by a society (Adanır, 2003, pp. 52-53).

A motion picture can engage in advocacy on human rights with the theme of law and justice, which it fictionally encodes on the screen. (Kamir, 2005, p. 269). A film, as a text with an assertion and based on a theoretical basis (Elsaesser \& Hagener, 2014, p. 12), creates a conscious value for these themes (Kamir, 2005, p. 269) by enabling us to discover what is happening around us through seeing (Elsaesser \& Hagener, 2014, p. 158). Indeed, the cinema narrative has always been coordinated, and is never without reason (Metz, 2012, p. 107). The critique of the documentary film 'No Gold for Kalsaka' that is seen to have this highlighted scope in some ways, should be approached within this perspective.

\section{Review of the Film 'No Gold for Kalsaka'}

'No Gold for Kalsaka'3 is a film aimed at such a historicity, and entirely created under social conditions. The thing that the film does is to communicate with other people around the world by announcing a community's recent experience of social injustice through the cinema. The cinematic narrative of 'No Gold for Kalsaka', as a documentary film in terms of its genre, not only reflects a real story, but also takes the above-mentioned function as a mission.

The cinema theory of the movie 'No Gold for Kalsaka' contains a cinematic technique and narrative, in which this situation can be observed directly and inherently. Including both real and fictional

3 'No Gold for Kalsaka' is a documentary movie that released in 2019. The movie is written and directed by Michel K. Zongo. The producers of the film are Michel K. Zongo and Florian Schewe. The film is awarded Best Documentary at the Africa Movie Academy Awards 2020 by the Africa Film Academy (Africa Film Academy, 2020). 
characters in the film shot as a documentary, and thus incorporating a fictional film narrative into the real story is an effort to strengthen the argumentation of the film. At the very beginning of the film, we see three horse riding strangers reminding of old-time cowboys, visiting Kalsaka. In the course of the story, these foreigners, who we see in the town for a while with an arrogant manner in a few intermediate scenes, leave Kalsaka by riding their horses towards the sun at the end of the film, as in the Western movies. The music we hear in these scenes already enables us to recall the Western atmosphere. In this representation that symbolizes colonialism, foreign horsemen are none other than the international companies that left destruction in Kalsaka.

The movie 'No Gold for Kalsaka' expresses the constant sovereignty of a community living in Africa over its own lands, and addresses the memory of this society by underlining their vitals which they have from past to present. Cinema films, aiming to make the audience think about what happened or what will happen to them in the society they live in and trying to create a sense of belonging by bringing political responsibilities to the agenda (Dorsay, 2003, p. 40), create national consciousness by the film stories built on a national struggle in the process of creating history on the axis of selfdetermination, and refresh the national memory. 'No Gold for Kalsaka' is also a documentary film that attempts to do so. The movies like this contribute to the development of a people's determination on their future and on their character of independence.

'No Gold for Kalsaka' is a work of art that concerns to create a public opinion about the bad experiences of the Kalsaka people, as a documentary film that takes the trouble of making a sound against injustice from the cinema screen. The audience figures out from the movie that locals want to determine their future by regaining their past rights that were only unfairly and unjustly taken away. "We were ignorant", says the mayor, elder villagers, and farmers in the film. However, it is understood from the movie that they are now learning about their rights and seeking justice. Focusing on the lives of the Kalsaka people with a creative artistic sensibility, and a political and legal perspective, the film underlines the fraud of the multinational gold company in the small town of Kalsaka, and the greed of the capital owners.

\subsection{Plot of the Film}

The film 'No Gold for Kalsaka' makes the voices heard of the people of Kalsaka who decide to fight against the injustices they experienced and try to get their rights back. The movie is about obvious injustice experienced by the people of Kalsaka and the struggle of the locals under the leadership of the lead character Jean-Baptiste to protect their human dignity.

The film depicts the destruction of the gold mines, which are the natural resources that the residents of Kalsaka have sustained their lives for thousands of years, with the arrival of foreigners, and what happened afterwards with the expressions of the local people who witnessed this. With the mystery over the story of the film disappeared in a short time, the reality reveals the truth that employment, health, education and development that were promised to the people of Kalsaka in return for the operation of gold mines were not fulfilled. The movie sets forth the claims of Kalsaka people that both the officials of the Burkina Faso government and the multinational company have not complied with the agreement.

It is clearly highlighted in the movie that due to the chemicals used for gold extraction, and the 
contamination and drying of groundwater, diseases have increased in Kalsaka, and that mining activities have destroyed the hill which is sacred to the people of Kalsaka, and have eliminated access to this area as a worship center in Kalsaka. Therewithal, the agricultural lands have been severely damaged because of the mining, and the livelihoods of the Kalsaka farmers based on agricultural production have been destroyed.

The desperation of the Kalsaka people, who face poverty because of the foreigners' gold processing activities, is explained to the audience through the cinema screen. Moreover, the danger they face due to the destruction of their vital natural resources such as water because of the environmental damage caused by this capitalist plundering is unfolded.

\subsection{The Direct Fixation of the Right to Economic Self-Determination in the Film}

Today, with the changes and transformations experienced in colonialism, the dimension of this injustice experience becomes much more evident with its economic, social and political aspects. The imperialist powers desire to maintain the order of exploitation based on occupation and domination as in the past, not only through state organizations or country governments, but also through international corporations and multinational companies who have legal entities. In that sense, colonialism is not abolished, so to speak, it wears masks and is more professional now.

In this respect, while keeping a focus on the injustice experienced by the Kalsaka people, the film 'No Gold for Kalsaka', essentially describes the colonialist attitudes and colonial policies that continue throughout the world, especially in Africa, in the case of Kalsaka, with a critical cinema perspective. Moreover, it reveals that the exploitation order continues. The film emphasizes the necessity of the people of Kalsaka to be able to get their rights back by not being satisfied with this functionality, and argues that there should be alternatives that will provide compensation for the damages which they have suffered from.

This mission of advocacy is essentially on the shoulders of not only the filmmakers, but also the lawyers above all. As a result of the awareness that has been attempted to create with the film regarding the painful experiences of the Kalsaka people and the public opinion that is attempted to be achieved, it is only possible to eliminate this unlawfulness by law. At this point, it can be mentioned that lawyers should undertake this mission.

There are multiple legal ways that can be used to remedy the unfair experiences in Kalsaka, which the film mentions and deals with. However, among these, the concept of self-determination as a legal theory and the right to economic self-determination as a law rule may provide more efficiency. Addressing the issue in the perspective of economic self-determination can provide an active legal functionality regarding the events in Kalsaka, as conveyed by the film. Accordingly, the following points can be highlighted.

Self-determination is an undeniable right, as a jus cogens rule of law, and it has been recognized to the peoples. Therefore, the people of Kalsaka can claim this right. The essential challenge here is the agreement between the multinational companies and government of Burkina Faso. As the government of Burkina Faso has sovereignty over the Kalsaka territory, the relevant agreement can be said to be legal. However, self-determination as a right granted to peoples can lead to the questioning of the legitimacy of this legality. In this case, the responsibilities of the government of Burkina Faso within 
the framework of self-determination should be discussed. Although the government of Burkina Faso has made legal agreements with multinational companies in the concrete case, this legality cover can be overcome by determining the legitimacy of these transactions. In addition, it is clear from the statements of local people in the film that the indigenous people did not have the legal wills with the misleading promises of the other party in the contracts they signed for the use of their estates. Also, the other party of the contracts has not fulfilled the obligations of in these contracts.

Prominent international human rights conventions such as the UN Charter and the Twin Covenants, to which almost all states of the world are parties, and regional human rights conventions like African Charter on Human and Peoples' Rights have secured the right to self-determination, and various declarations put into action by the UN highlighted the economic dimension of this right. In these, it is underlined that a permanent sovereignty over natural resources belongs to the peoples who own those resources. In this case, it is certain that the people of Kalsaka have the right to freely own natural resources and riches such as gold reserves or water, to use and benefit from them as they wish. It has been demonstrated in international human rights documents that they have full control over them. Additively, in some of the above-mentioned international human rights law documents issued by the UN, it is clearly emphasized that the sovereignty over natural resources should be applied to the benefit of the peoples. It is clearly deduced from the film that the relevant company and the state of Burkina Faso have acted contrary to these issues in Kalsaka, and have not cared for the benefits of the Kalsaka people.

The people of Kalsaka can make their voices heard in the international community about the unlawfulness of the colonial activities carried out on their land. Because the colonialist thought lies at the root of the human rights violations experienced in Kalsaka, and self-determination is the legal antidote to colonialism. The legal interpretation of whether they meet the criteria of being the subject of the right as people can be extended to idealize human rights. If the above-mentioned legality cover is exceeded, based on the authority provided by this right, it can apply to international organizations such as the UN and African Union through the State of Burkina Faso. In addition, if international dispute resolution methods come into the agenda, it may demand the fulfilment of its rights and compensation of its damages by showing the above-given international arbitration verdicts as a precedent based on the right to economic self-determination.

\section{Conclusion}

The people of Kalsaka, who are the residents of a small settlement in West African country Burkina Faso, have gained their livelihood with the craft they make from the gold they extract from their lands throughout history. This economic activity ends with the industrial intervention of a multinational mining company that launched the industrial gold mine in 2008. A multinational mining corporation, which started gold mining in Kalsaka after the permission of the government of Burkina Faso, begins to destroy the natural resources, that also contain water and are vital for the lives of Kalsaka villagers, by digging the soil. Thus, in Burkina Faso, which means 'land of honest people' (Dr. Y., 2013), the first steps have taken for a series of tricks and rights abuses. It did not take long for the mountains of gold promised to the Kalsaka people to melt. Words like jobs to unemployed peasants, scholarships for children, development aid have remained as promise and have not come true. Acting as an extension of the colonialist understanding, the company left Kalsaka after extracting 18 tons of gold. 
Residents of the Kalsaka town of Burkina Faso are disappointed by the vain promises made by the government and multinational gold mining companies. Today, the people of Kalsaka whose natural resources were destroyed and taken away from them are fighting a war of honour to sustain their lives and ensure their rights are restored.

It is crucial to determine the roles that the law can play in eliminating this unlawfulness by entering through the door that the film opens. Therefore, it is up to the lawyers to determine the legal institutions and legal rules that can be applied to unlawful events in Kalsaka. In this case, many legal issues can be applied, but in this article, self-determination that is the most prominent theoretical subject in this aspect has been preferred.

As a human right, the right to economic self-determination, guaranteed by international human rights treaties, can be a functional legal tool in the struggles of the Kalsaka people. Theoretically, this right ensures the full sovereignty of indigenous peoples over their natural resources through positive legal arrangements. It brings an opportunity to hold an account in human rights law against violations in Kalsaka and provide compensation.

\section{Bibliography}

Adanır, O. (2003). Sinemada Anlam ve Anlatım. İstanbul: Alfa.

Akçay, D. (1998). Selfdeterminasyon: Bir İlkenin Önlenemez Nötralizasyonu. Murat Sarıcı Armağanı, 27-37, İstanbul: Aybay.

Balcı, M. \& Sönmez, G. (2001). Temel Belgelerde Insan Hakları. İstanbul: Danışman.

Bauböck, R. (2004). Paradoxes of Self-Determination and the Right to Self-Government. IWE Working Paper, 42, 1-28.

Bazin, A. (1993). Sinema Nedir? (İbrahim Şener, Trans.). İstanbul: Sistem.

Bilge, A.S. (1959). Milletlerin Mukadderatlarını Kendilerinin Tayin Etmeleri Prensibi. Ankara Üniversitesi Siyasal Bilgiler Fakültesi Dergisi, 14(1), 132-146.

Bring, O. (2003). Halkların Kendi Kaderini Tayin Etme Hakkı. Serbesti, 15, $22-34$.

Crawford, J. (2001). The Right of Self-Determination in International Law: Its Development and Future. In. Philip Alston (Ed.), Peoples' Rights (pp. 7-67). New York: Oxford University Press.

Cassese, A. (1995). Self-Determination of Peoples. Cambridge: Cambridge University Press.

Connor, W. (1994). Ethnonationalism, The Quest for Understanding. New Jersey: Princeton University Press.

Chemillier-Gendreau, M. (1998). Uluslararası Hukuk, Devletler Hukuku, Halklar Hukuku. In. Jean Leca (Ed.), Uluslar ve Milliyetçilikler. İstanbul: Metis.

Dorsay, A. (2003). Sinema ve Çağımız. İstanbul: Remzi.

Elsaesser, T. \& Hagener, M. (2014). Film Kuramı. Ankara: Dipnot.

Gardam, J.G. (1993). Non-Combatant Immunity As a Norm of International Humanitarian Law. Londra: Martinus Nijhoff.

Kamir, O. (2005). Why 'Law-and-Film' and What Does it Actually Mean? A Perspective. Continuum, 19(2), 255-278.

Kolker, R.P. (2018). Politics Goes to Movies Hollywood, Europe and Beyond. New York: Routledge.

Metz, C. (2012). Sinemada Anlam Üstüne Denemeler (Oğuz Adanır, Trans.). İstanbul: Hayalperest. 
McLuhan, M. (2005). Yaradanımız Medya (Ünsal Oskay, Trans.). İstanbul: Merkez Kitaplar.

Monaco, J. (2014). Bir Film Nasıl Okunur? Sinema Dili, Tarihi ve Kuramı Sinema, Medya ve Mültimedya Dünyası (Ertan Yılmaz, Trans.). İstanbul: Oğlak.

Nowak, M. (2018). Menschenwürde und Menschenrechte. Wien: Picus Verlag.

Oran, B. (1997). Azgelişmiş Ülke Milliyetçiliği: Kara Afrika Modeli. Ankara: Bilgi.

Özdek, Y. (2000). Uluslararası Politika ve Insan Hakları. Ankara: Öteki.

Pazarcı, H. (2013). Uluslararası Hukuk Dersleri (2. Kitap). Ankara: Turhan.

Potier, T. (2001). Conflict in Nagorno-Karabakh, Abkhazia and South Ossetia; A Legal Appraisal. Dordtrecht: Kluwer Law International.

Ryan, M. \& Kellner, D. (2016). Politik Kamera (Elif Özsayar, Trans.). İstanbul: Ayrıntı.

Tomuschat, C. (Ed.). (1993). Modern Law of Self-Determination. Londra: Martinus Nijhoff.

Tarhanlı, T. (1991). Uydular Aracılı̆ı̆yla Yer Doğal Kaynaklarının Uzaktan Algılanması ve Uluslararası Hukuk. İstanbul: Edebiyat Fakültesi Basımevi.

Yaylagül, L. (2018). Sinema Toplum Siyaset. Ankara: Dipnot.

Zhu, Y. \& Biachford, D. (2006). Ethnic Disputes in International Politics: Manifestations and Conceptualizations. Nationalism and Ethnic Politics, 12(1), 25-51.

Internet Sources

African Union. (n.d.). African Charter on Human and Peoples' Rights. Retrieved from https://www.achpr.org/legalinstruments/detail?id=49. Accessed on: 14/04/2021.

Africa Film Academy. (2020). Africa Movie Academy Awards. Retrieved from https://www.ama-awards.com/amaa2020-winners. Accessed on: 14/01/2021.

Dr. Y. (2013). Why the name: Burkina Faso?. African Heritage. Retrieved from https://afrolegends.com/2013/09/12/whythe-name-burkina-faso/. Accessed on: 18/01/2021.

Extractive Industries Transparency Initiative. (2011). Validation Report. Retrieved from https://eiti.org/files/EN_Validation\%20Report\%20-\%20EITI\%20Burkina\%20Faso.pdf. Accessed on: 16/12/2020.

Jamasmie, C. (2012). Cluff Gold expands its mining operations in West Africa. Mining.com Retrieved from https://www. mining.com/cluff-gold-expands-its-mining-operations-in-west-africa/. Accessed on: 14/12/2020.

Proactive Investors. (2009). Cluff Gold fully commissions Kalsaka gold mine in Burkina Faso. Retrieved from https:// www. proactiveinvestors.co.uk/companies/news/4960/cluff-gold-fully-commissions-kalsaka-gold-mine-in-burkina-faso--6733.html. Accessed on: 14/12/2020.

United Nations. (n.d.). Charter of the United Nations. Retrieved from https://www.un.org/en/about-us/un-charter/full-text. Accessed on: 22/12/2020.

United Nations. (n.d.). Charter of Economic Rights and Duties of States. Retrieved from https://www.un.org/ga/search/ view_doc.asp?symbol=a/res/3281(XXIX). Accessed on: 11/01/2021.

United Nations. (n.d.). Declaration on the Granting of Independence to Colonial Countries and Peoples. Retrieved from https://legal.un.org/avl/ha/dicc/dicc.html. Accessed on: 27/12/2020.

United Nations. (n.d.). Declaration on the Right to Development. Retrieved from https://legal.un.org/avl/ha/drd/drd.html. 
Accessed on: 30/12/2020.

United Nations. (n.d.). International Covenant on Civil and Political Rights. Retrieved from https://treaties.un.org/doc/ Treaties/1976/03/19760323\%2006-17\%20AM/Ch_IV_04.pdf. Accessed on: 29/12/2020.

United Nations. (n.d.). Permanent Sovereignty over Natural Resources. Retrieved from https://legal.un.org/avl/ha/ ga_1803/ga_1803.html. Accessed on: 11/01/2021.

United Nations. (n.d.). Right to Exploit Freely Natural Wealth and Resource. Retrieved from https://digitallibrary.un.org/ record/211441. Accessed on: 11/01/2021.

United Nations. (n.d.). Vienna Convention on the Law of Treaties. Retrieved from https://legal.un.org/ilc/texts/instruments/english/conventions/1_1_1969.pdf. Accessed on: 18/12/2020.

Van Wyngaardt, M. (2012). Cluff Gold to become Amara Mining. Mining Weekly. Retrieved from https://www.miningweekly.com/article/cluff-gold-to-become-amara-mining-2012-10-01. Accessed on: 14/12/2020. 